\title{
Neanderthal diet in fluvial environments at the end of the Middle Pleistocene/early Late Pleistocene of PRERESA site in the ManzanaresValley (Madrid, Spain).
}

\author{
José Yravedra ${ }^{\mathrm{a}, *}$, Susana Rubio-Jara ${ }^{\mathrm{b}}$, Joaquín Panera ${ }^{\mathrm{b}}$, Jan van der Made ${ }^{\mathrm{c}}$, \\ Alfredo Pérez-González ${ }^{\text {b }}$ \\ a Departamento de Prehistoria, Universidad Complutense de Madrid, C/ Prof. Aranguren s/n, 28040, Madrid, Spain \\ b CENIEH, Centro Nacional de Investigación sobre la Evolución Humana, Paseo de la Sierra de Atapuerca 3, 09002, Burgos, Spain \\ ${ }^{\text {c } M u s e o ~ N a c i o n a l ~ d e ~ C i e n c i a s ~ N a t u r a l e s ~(C S I C), ~ C / ~ J o s e ́ ~ G u t i e ́ r r e z ~ A b a s c a l ~ 2, ~ 20006, ~ M a d r i d, ~ S p a i n ~}$
}

\section{A R T I C L E I N F O}

\section{Article history:}

Received 11 December 2017

Received in revised form

11 January 2018

Accepted 23 January 2018

Available online $\mathrm{xxx}$

\section{Keywords:}

Neanderthal

Taphonomy

Middle palaeolithic

Early late pleistocene

Iberian peninsula

Manzanares valley

\begin{abstract}
A B S T R A C T
Most Middle Palaeolithic sites with faunal remains processed by humans in the Iberian Peninsula are located in rock shelters or caves. PRERESA is one of the few open-air sites, dating to the end of the Middle or early Late Pleistocene, in which faunal remains associated with lithic industry has been recorded. At least one individual of Mammuthus/Elephas has been identified, as well as two individuals of Bos primigenius, a further two of Haploidoceros mediterraneus, and other mammals of different sizes. The sample is well preserved; carnivore activity is scant and the remains were buried shortly after death. The site is located in the floodplain of the Manzanares river, in an environment of forest and open areas, characterized by herbaceous plants and river woodlands which developed in a mild climate with some humidity. One Haploidoceros and one auerochs were almost complete and semi anatomically connected. A proboscidean, one of the auerochs and an unidentified mammal show conspicuous evidence of having been exploited by human beings. Lithic knapping was aimed at flake production. All phases of the operational chain are represented, which suggests that the lithic assemblage was manufactured with the purpose of processing meat. The scantly elaborated technical schemes of the lithic industry, together with the limited evidence of human processing of faunal remains as well as the presence of animals deposited in a natural way could suggest that this site was used by Neanderthals only sporadically. However, the presence of certain taxa such as proboscidea, auerochs and four other mammal species of different sizes, which were a anthropically processed, could indicate that the site was visited recurrently by human groups with the purpose of processing such mammals. The purpose of this paper is to analyse the taphonomic history of the site, as well as to add to the knowledge of the Neanderthal group behaviour patterns.
\end{abstract}

() 2018 Elsevier Ltd and INQUA. All rights reserved.

\section{Introduction}

The Manzanares and Jarama valleys (hereafter MJV), are well known for providing one of the highest concentration of sites with evidence of human exploitation of proboscideans during the Middle and Late Pleistocene in Europe (Panera et al., 2014; Rubio-Jara et al., 2016; Yravedra et al., 2017, in this volume). This can be seen at several sites, such as Áridos (Santonja et al., 1980; Villa,

\footnotetext{
* Corresponding author.

E-mail address: jyravedr@ghis.ucm.es (J. Yravedra).
}

1990; Yravedra et al., 2010), Arriaga Ila (Rus and Vega, 1984; Panera et al., 2014), EDAR Culebro 1 (Yravedra et al., 2014) and PRERESA (Rubio-Jara, 2011; Yravedra et al., 2012; Panera et al., 2014), among others. However, evidence of human consumption of other species of mammals in these fluvial deposits are not as numerous. In the sites of Valdocarros (Rubio-Jara et al., 2016), Estanque de Tormentas de Butarque and Tafesa (Yravedra, 2010), cut and/or percussion marks have been recorded on the remains of deer, large bovids, horses, and even beavers (Áridos 1, observed by Yravedra) from Middle Pleistocene deposits. The only recorded evidence for the later Middle Pleistocene and early Late Pleistocene comes from archaeological excavations carried out in the first half 
of the 20th Century, without proper methodologies and with little accurate stratigraphic contexts (Panera and Rubio-Jara, 2002): auerochs in the Santa Elena (MIS 6) and Arriaga sandpits (MIS 6); horse remains in Areneros (= sandpits) of Viuda Martínez (MIS 5) and Santa Catalina (MIS 4-3), and large bovid bones in La Aldehuela (MIS 5-4), even rhinoceros in the Arenero de Pedro Jaro (MIS 4-3). The data outlined in this paper permits a fundamental approach to the diversity of animal resources exploited by Neanderthals in MJV during the Middle and Late Pleistocene (Panera and Rubio-Jara, 2002; Sesé and Soto, 2002a, 2002b; Panera et al., 2014).

Several sites have been excavated in MJV with modern technology, which allows us to tackle the analysis of the behaviour of the human groups that occupied this area during the Pleistocene. Thanks to the lithic industry and associated faunal remains from the second half of the Middle Pleistocene retrieved from sites such as Áridos (Santonja et al., 1980), Valdocarros (Rubio-Jara et al., 2016), Tafesa (Baena Preysler and Baquedano, 2010), Arriaga IIa (Rus and Vega, 1984; Silva et al., 2013; Panera et al., 2014) and Estanque de Tormentas de Butarque H-02 (De los Arcos et al., 2008; Laplana et al., 2015), it is possible to study the survival strategies of the hominins that occupied these sites. The sole presence of lithic industry in Cien Fanegas (Baena et al., 2010), Los Ahijones (Bárez del Cueto et al., 2016), and El Cañaveral (Baena et al., 2008a, 2008b, 2015), these last two located to the MJV interfluve, suggests that the main activity at these sites was manufacturing tools. There is less evidence for MIS 6/5: EDAR Culebro 1 (Yravedra et al., 2014) and HAT (Panera et al., 2005), with associated lithic industry and faunal remains, only show slight evidence of human activity, whereas in La Gavia (López-Recio et al., 2005), Los Estragales (Pérez-González et al., 2008; Rubio-Jara, 2011), and El Cañaveral large accumulations of lithic industry with no associated bone remains have been recorded.

In the Iberian Peninsula, most late Middle Pleistocene or early Late Pleistocene sites which have faunal remains processed by human beings and associated with lithic industry are located in rock shelters or caves: Navalmaíllo (Arsuaga et al., 2012; Márquez et al., 2013), Valdegoba (Díez, 2007), Bolomor (Blasco and Fernández-Peris, 2012a, 2012b; Sañudo et al., 2016), Las Callejuelas (Domingo et al., 2017), El Castillo (Cabrera, 1984; Bischoff et al., 1992). PRERESA is one of the few middle Palaeolithic (late Middle-early Late Pleistocene) open air sites in the Iberian Peninsula in which faunal remains associated with lithic industry has been recorded, together with Arriaga IIa (Rus and Vega, 1984; Silva et al., 2013; Panera et al., 2014) and Solana del Zamborino (Martín Penela, 1987; Jiménez-Arenas et al., 2011). Conspicuous evidence of the human exploitation of large mammals (a proboscidean, an auerochs and a number of other large mammals have been identified), as well as the knapping of lithic tool sat the site (probably to be used for the processing of meat) have been recorded in PRERESA (Rubio-Jara, 2011). The results are presented in this paper, with the aim of analysing the taphonomic history of this site, and contributing to the knowledge of the territory management of the neanderthals in the interior of the Iberian Peninsula.

\section{The archaeological site of PRERESA}

The open air site PRERESA is located to the lowest segment of the river Manzanares, $18 \mathrm{~km}$ southeast of Madrid, Spain (Fig. 1). In this area, the fluvial system is affected by synsedimentary subsidence due to the karstic dissolution of the gypsum in the substrate, a well-known phenomenon in the large tertiary continental basins in Spain and the nearby valley of the river Jarama (Pérez-González, 1971). The main anomalous morphostratigraphical features that produce this type of subsidence include great thickening of fluvial deposits and superposition of the deposits correlative to different terrace levels, which can reach over 40 m (Pérez-González, 1971; Pérez-González et al., 2008). The terraces involved in the area which extends downstream from Madrid city are the youngest levels of the second half of the Middle Pleistocene, as well as those from the Late Pleistocene. All these terraces form the Complex Terraces of Butarque, here after CTB (Goy et al., 1989). Upstream from the city of Madrid, over siliciclastic bed rock, thirteen levels of stepped alluvial terraces have been identified from 4 to $-5 \mathrm{~m}$ the lower to $+95 \mathrm{~m}$ the uppermost, with a maximum depth of $6-7 \mathrm{~m}$.

PRERESA (Getafe, Madrid) is located close to the upper section of the CTB stratigraphic sequence, in a gravel pit (PRERESA) on the right bank of the lower course of the river Manzanares. There is an open mining front $14 \mathrm{~m}$ in depth where Carrillo et al. (1978) and Arche (1983) established different fluvial cycles characterized by fining-upward sequences, which begin with channel facies of gravel and sand deposits and ends with overbank facies. According to the OSL analysis, the site of PRERESA dates to the second half of MIS 5 (Rubio-Jara, 2011; Yravedra et al., 2012). The date of $84.126 \pm 6.533 \mathrm{ka}$ BP was consistent with the presence of Microtus cabrerae (Sesé et al., 2011a). However, a new date range of between $169 \mathrm{ka}$ and $270 \mathrm{ka}$ has been obtained by ESR. Taking into consideration that Microtus cabrerae is a direct descendent of Microtus brecciensis, and that the data provided for this species in Valdocarros fall within MIS 8/7 (Panera et al., 2011; Sesé et al., 2011b), as well as the possible presence of Microtus cabrerae in MIS 6 sites (Laplana et al., 2015; Foury et al., 2016), the most probable ESR date is the early MIS 6 (Moreno et al.,2017 in this volume).

An area of $255 \mathrm{~m}^{2}$ was excavated in three campaigns between 2003 and 2006. The fossil record of PRERESA consists of an important association of bone remains and lithic industry which has been retrieved from a single clay level $30 \mathrm{~cm}$ thick. This level was deposited during a flood episode, as the site is located within the floodplain of the Manzanares river (Fig. 2).

The lithic tool collection consists of 754 pieces, most of them made of flint, except for six pieces made of quartz. The lack of macrotools is outstandig, as otherwise the ensemble could have been adscribed to the Acheulean technocomplex. The operative chains of the flint pieces are complete; highly cortical flakes, several refits and knapping remains have been recorded, which suggests that the nodules were brougt and knapped on site. The purpose of the knapping method was to obtain flakes greater in width than in length, probably for easier gripping. Plain flakes and debitage remains prevail over retouched tools. Cores have been intensively exploited, which prevented from determining the operative scheme in half of the pieces. Retouched tools consist of retouched flakes, denticulates, compound tools, a scraper and a burin (RubioJara, 2011).

The faunal record has provided a great variety of species. Bos primigenius, Haploidoceros mediterraneus, Capreolus sp., Equus sp., and Palaeoloxodon/Mammuthus have been identified among the macromammals, as well as carnivores such as Vulpes vulpes, Panthera leo and Meles meles (Yravedra et al., 2012; Made and Mazo, 2015). The presence of Haploidoceros is remarkable, since there are very few fossil localities which record this genus.

The micromamals identified at the site were Erinaceus europaeus, Crocidura russula, Rhinolophus ferrumequinum, Rodentia, Eliomys quercinus, Apodemus sp., Cricetulus (Allocricetus) bursae, Arvicola aff. sapidus, Microtus cabrerae, Microtus duodecimcostatus and Oryctolagus cuniculus (Sesé et al., 2011b). The amphibians and reptiles identified include Palobate cultripes, Pelodytes sp., Bufo bufo, Bufo calamita, Hylas sp., Pelophyas perezi, Timonlepidus, Psammodromus cf., algirus, Blanus sp., Natrix maura, Coronella sp. and Viperalatastei (Blain et al., 2013). From a paleoclimatic point of view, these species suggest mild and slightly damp conditions, with good development of both forest and open areas, with bush, herbaceous 


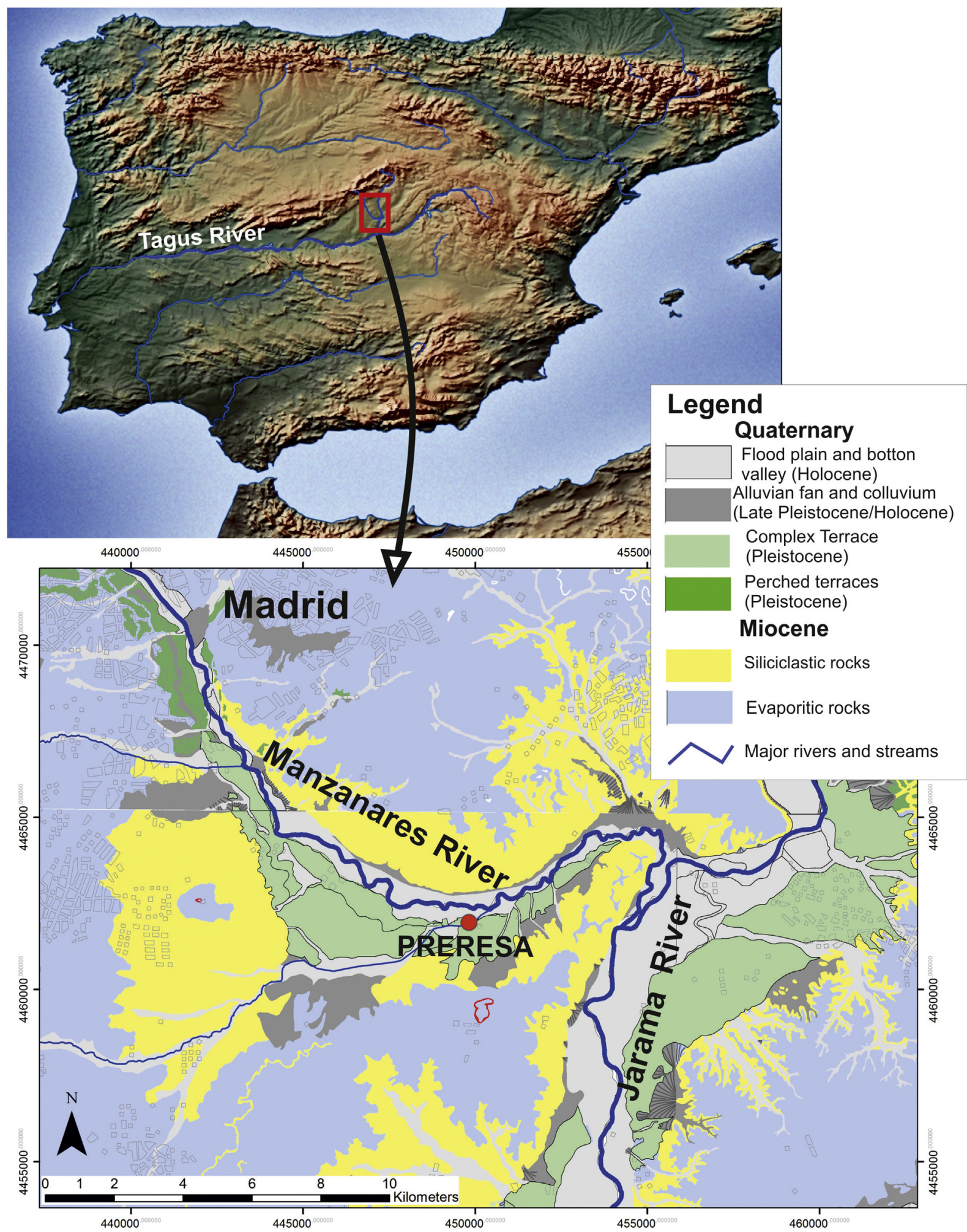

Fig. 1. Location of PRERESA in the Complex Terrace of Butarque at Manzanares Valley (Madrid, Spain).

plants and riverside woodlands (Sesé et al., 2011b; Blain et al., 2013).

\section{Materials and methods}

This paper completes the research carried out by Yravedra et al.
(2012) with the presentation of the taphonomic analysis of the bone remains retrieved from PRERESA. The bone assemblage from PRERESA consists of 1262 remains, including the 82 remains of proboscidean which were presented in detail by Yravedra et al. (2012). In order to complete this study, we have focused on the analysis of the other macrovertebrates recovered from the site, 


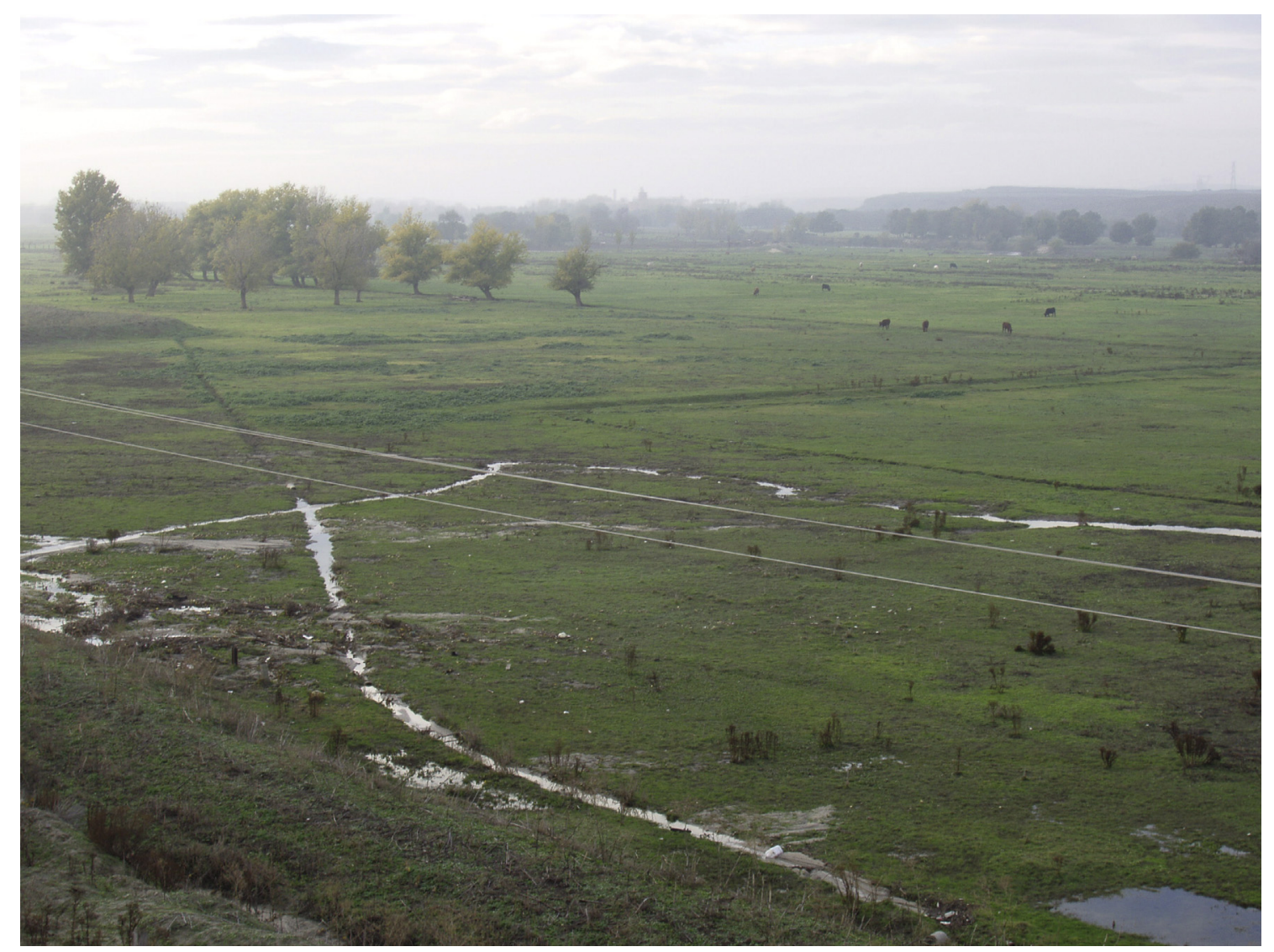

Fig. 2. Current floodplain at the Manzanares river.

although generic references to the proboscidean remains are also occasionally given.

The main methods and techniques used in the study are described in the following lines.

Taxonomic identifications were based mainly on teeth and reference material. However, in those cases when such determination was not possible, fragments were attributed to animal weight/size classes following Bunn (1982), where "small-sized" are considered sizes 1 and 2, "medium-sized" refers to size 3, "large" refers to sizes $4-5$ and extra large refers to size 6 .

Faunal remains were quantified by NISP (Number of Identifiable Specimen), MNE (Minimum Number of Element) and MNI (Minimum Number of Individuals). MNE estimates include limb shafts, age, size and biometrics. Elements were quantified according to Yravedra and Domínguez-Rodrigo (2009). For limb bone identifications, factors such as shaft thickness, section shape, and medullar surface properties were considered (Barba and DomínguezRodrigo, 2005). MNI estimates considered element side and ontogenetic age (Brain, 1969). To assess mortality patterns, specimens were assigned to one of three categories based on tooth eruption and crown wear: infantile, juvenile-prime adult and adult.

Skeletal part profiles were organized into four anatomical regions: cranial (i.e. horn, cranium, mandible and teeth), axial (vertebrae, ribs, pelvis and scapula, sensu Yravedra and DomínguezRodrigo, 2009), upper appendicular elements (humerus, radius, ulna, femur, patella and tibia) and lower appendicular elements (metapodial, carpals, tarsals, phalanges and sesamoids). Long limb bones were further divided into upper (humerus and femur), intermediate (radius and tibia) and lower (metapodial) bones (Domínguez-Rodrigo, 1997).
Several procedures were followed to reconstruct site formation processes, assess site integrity, and evaluate the contribution of various biogenic agents to the faunal assemblage. Bone fragmentation was analysed according to three variables. Firstly, bones were divided into several categories according to their length: $<3,3,4,5$ $\ldots 10$ and $>10 \mathrm{~cm}$. Secondly, the percentage of partial representation of specimen according to types was analysed. Type 1 refers to specimens $<50 \%$ of length, type 2 to specimens with $>50 \%$ of total length and type 3 to complete specimens. Thirdly, shaft preservation was classified following Bunn (1982) circumference types, where type 1 refers to specimens with $<50 \%$ of the shaft circumference intact, type 2 to specimens with $>50 \%$ of the shaft circumference intact, and type 3 to specimens with an intact shaft circumference.

The impact of water activity was estimated with fragment size distributions and the presence of abrasion, polishing, rounded bones and carbonates (Voorhies, 1969). Signs of polishing, rounding or abrasion would be expected in transported assemblages, but also in non-transported assemblages exposed to circulating water and mobile sediments, such as those encased in sand strata (Thompson et al., 2011). Determining whether or not the assemblage is in primary versus secondary position is particularly important given the fluvial depositional context of the site.

Weathering was analysed following Behrensmeyer (1978). A high degree of weathering can affect the fragmentation and deterioration of bones. It is important to differentiate whether weathering alterations are affecting bones showing green and/or dry (including diagenetic) breakage patterns. To identify both types of breakage we followed Villa and Mahieu (1991) criteria. Dry breaks result in abundant breaks that are longitudinal and/or transverse to 
the axis of the bone and breakage planes that are uneven, rough, and possess micro-step fractures. They are also characterized by cortical medullary surface angles that are close to $90^{\circ}$. In contrast, green-broken specimens frequently have smoother surfaces and more abundant oblique breakage planes.

Additionally, a systematic search for bone surface modifications was carried out with $10 \times-20 \times$ hand lenses (following Blumenschine, 1995). Diagnostic criteria defined by DomínguezRodrigo et al. (2009) guided the identification of cut marks, whereas tooth and percussion marks were recorded following Blumenschine (1988, 1995). For comparative purposes, surface modifications include the evaluation of epiphysis and shaft areas (Blumenschine, 1988, 1995). Modifications are also quantified by element type and bone section (Domínguez-Rodrigo, 1997; Barba and Domínguez-Rodrigo, 2005) based on NISP values. The presence of tooth, percussion, and cut marks is recorded for the entirety of remains, although estimated percentages include only wellpreserved postcranial bone surfaces.

\section{Results}

\subsection{Taxonomic, mortality and skeletal profiles}

PRERESA has provided a sample of 1262 remains of several species, including an individual of undetermined proboscidean (Table 1); two individuals of auerochs, one of which is represented by a complete skeleton partially anatomically connected and scattered over $100 \mathrm{~m}^{2}$ (Figs. 3 and 4); a further two individuals of Mediterranean deer (Haploidoceros mediterraneus) partially anatomically connected and arranged in several sets (Figs. 5-7); and finally partial remains of roe deer, horse, lion and badger.

Additional remains belonging to undetermined small (size 2), medium (size 3) and large (size 4) animals were recovered (Table 1).

According to the identified MNI, the sample from PRERESA is not an extensive one ( 9 individuals). However, the taxa identified in the sample are interesting. This is the first site in the Manzanares Valley where the remains of Haploidoceros among the herbivores and lion among the carnivores have been identified. With regard to the age pattern, all individuals but the lion were adult (Table 1).

Although seasonality analysis has not been carried out with regard to the time of death of the animals, the presence of the antlers next to the Haploidoceros skull suggests that this specimen died between autumn and winter.

The skeletal profiles of PRERESA show a disparity in the representation of the taxa (Table 2). Some animals, such as roe deer, horse, badger and lion are represented by one single bone, whereas others, such as auerochs and Haploidoceros, have at least one

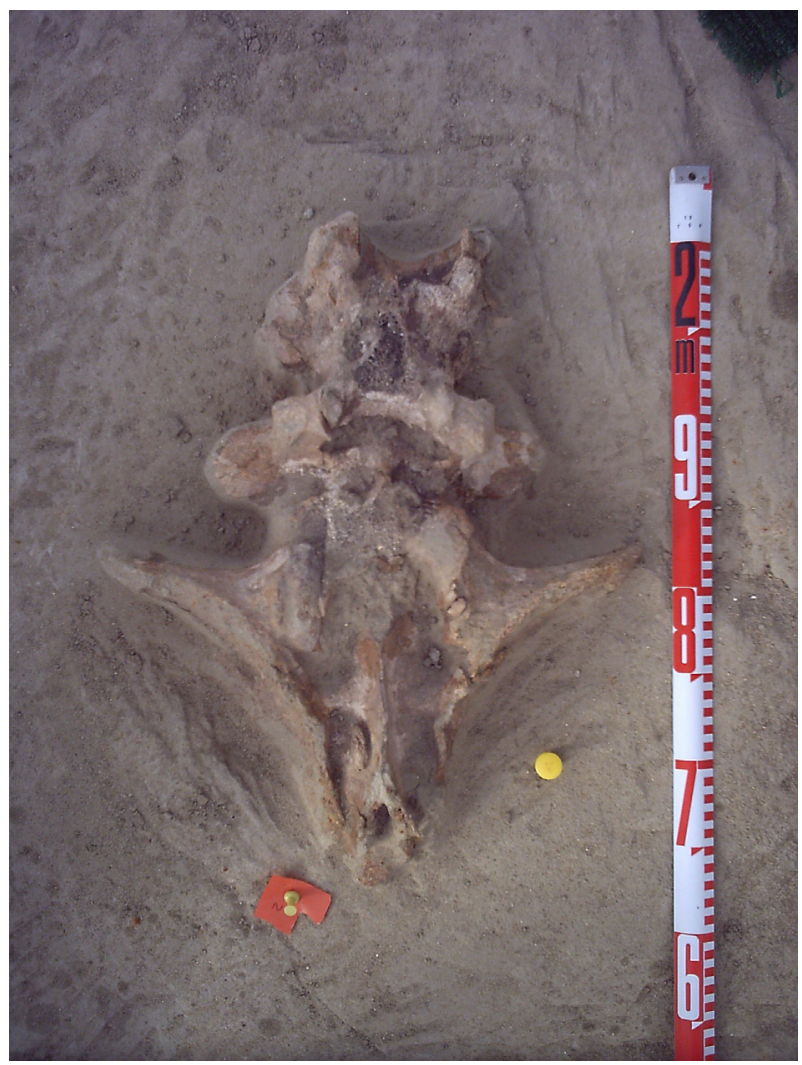

Fig. 3. Auerochs sacrum articulated with several vertebrae.

complete individual in semi anatomical connection (Figs. 3-7). Lastly, although the proboscidean is not complete, bones from all anatomical parts are represented, including cranial, axial and appendicular elements (Yravedra et al., 2012).

As regards the whole of the skeletal profiles recorded at PRERESA, and according to their classification as large (size 4), medium (size 3 ) or small (size 2), it can be observed that bones from all anatomical parts are represented in all groups (Table 3). Also, the representation profiles are not different from those observed in the MNE of Table 2. Therefore, it can be stated that animals of sizes 3 and 4 are completely represented in the site. Nevertheless, the lack of certain elements such as carpals and tarsals in size 3 animals are exceptional (Tables 2 and 3), as well as the low amount of small sized animal remains, among which axial elements (abundant rib fragments) stand out.

Skeletal profiles in which low density elements such as ribs,

Table 1

Representation of NISP and MNI identified at PRERESA.

\begin{tabular}{|c|c|c|c|c|c|c|}
\hline & NISP & $\%$ Total & \% Determ & MNI & $\%$ & AgePatern \\
\hline Mammuthu/Elephas & 82 & 6.5 & 20.0 & 1 & 10 & Adult \\
\hline Bos primigenius & 167 & 13.2 & 41 & 2 & 20 & Adult \\
\hline Equus ferus & 1 & 0.1 & 0.2 & 1 & 10 & Adult \\
\hline Haploidoceros mediterraneus & 156 & 12.4 & 38.1 & 2 & 20 & Adult \\
\hline Capreolus capreolus & 1 & 0.1 & 0.2 & 1 & 10 & Adult \\
\hline Panthera leo & 1 & 0.1 & 0.2 & 1 & 10 & Infant \\
\hline Vulpes vulpes & 1 & 0.1 & 0.2 & 1 & 10 & Adult \\
\hline Meles meles & 1 & 0.1 & 0.2 & 1 & 10 & Adult \\
\hline Total & 410 & & & 10 & & \\
\hline Indet Large size 4 & 255 & 20.2 & & & & \\
\hline Indet Medium size 3 & 35 & 2.8 & & & & \\
\hline Indet Small size $1-2$ & 77 & 6 & & & & \\
\hline Indet & 486 & 38.5 & & & & \\
\hline Total & 1263 & 100 & 100 & & 100 & \\
\hline
\end{tabular}




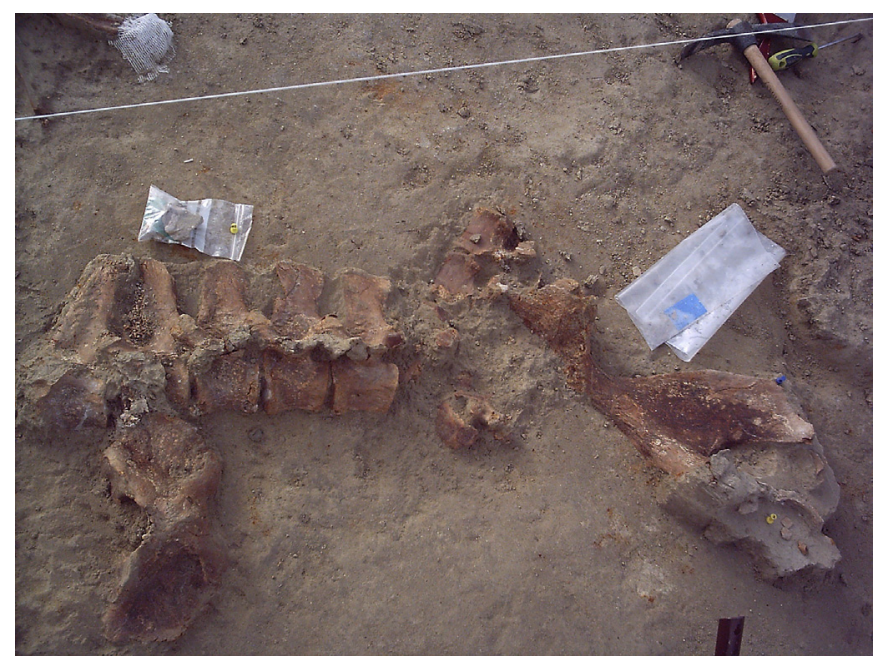

Fig. 4. Anatomical connection of several auerochs vertebrae.

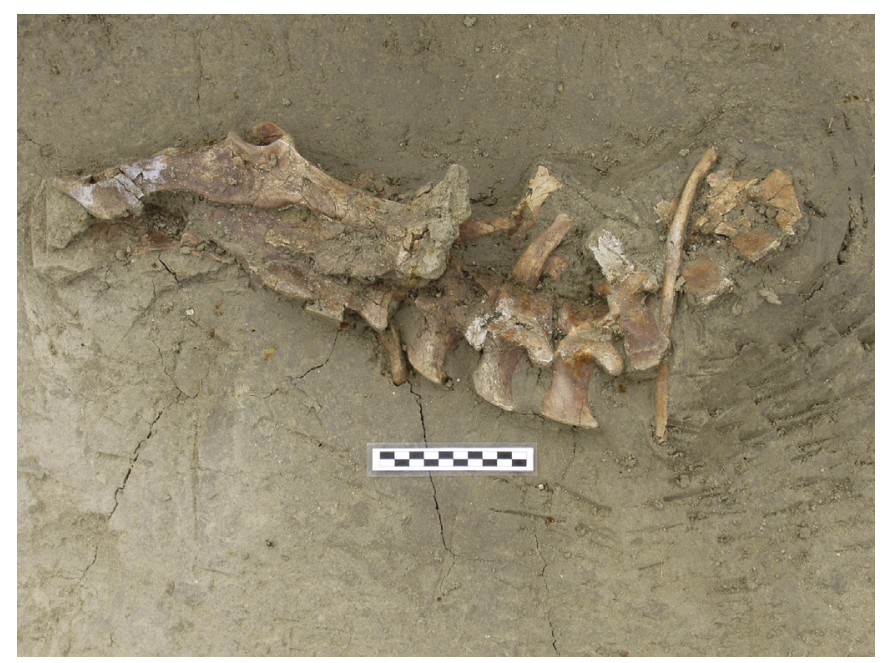

Fig. 5. Haploidoceros pelvis articulated with several vertebrae.

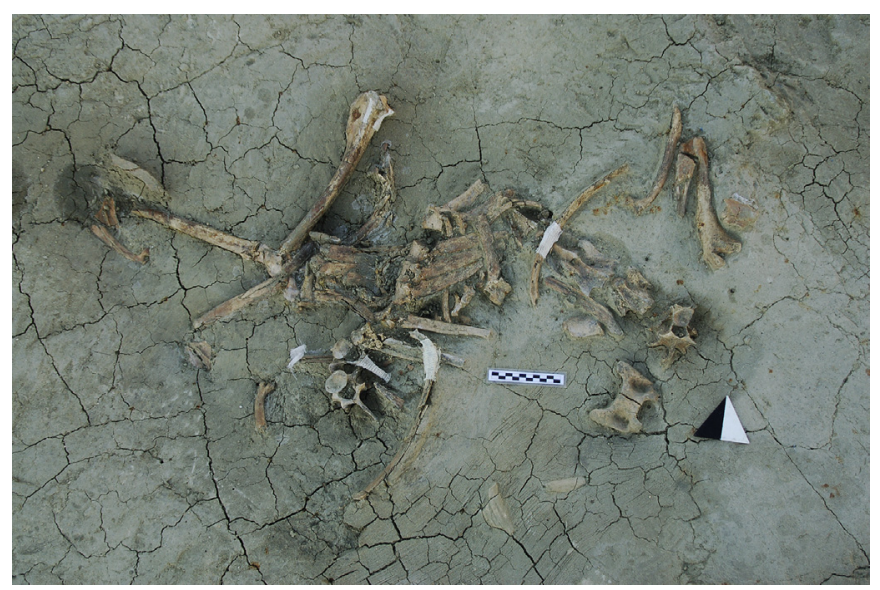

Fig. 6. Ensemble of Haploidoceros appendicular and axial bones in anatomical connection.

vertebrae and other axial elements are abundant (Tables 2 and 3) show that differential preservation is not overly prevalent in the

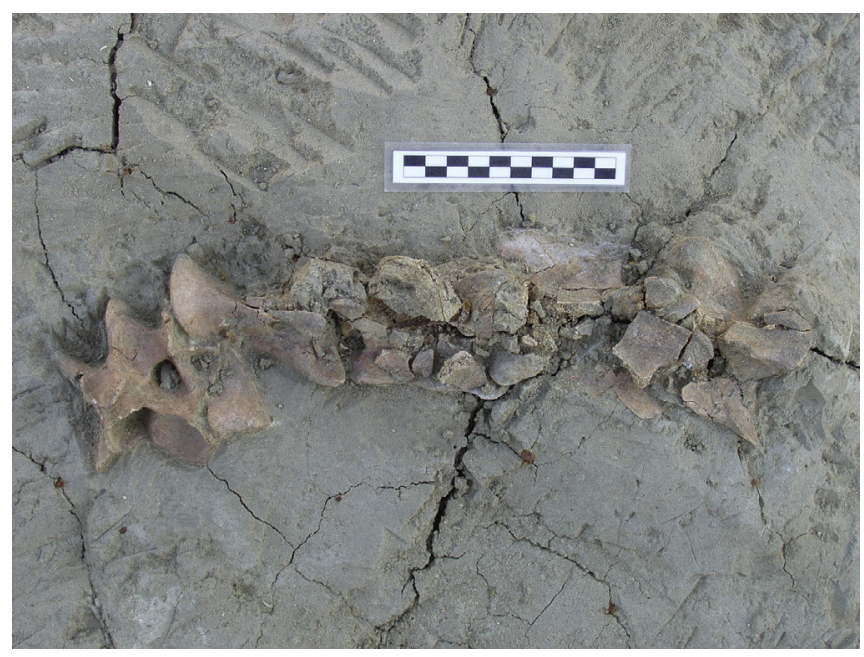

Fig. 7. Ensemble of Haploidoceros vertebrae in anatomical connection.

bone representation of the site. Therefore the pre-depositional and post-depositional processes that took place on the site have to be determined from taphonomic analysis alone.

\subsection{The taphonomic study}

The preservation of the bone sample is good, all anatomical parts are represented, and the presence of less dense remains such as the axial portions is exceptional, according to the skeletal profiles. This good condition is also evident in the taphonomic analysis.

Study of the fragmentation patterns, showed that, even excluding the proboscidean remains, the sample is little fragmented, at least $35 \%$ of the remains measure over $3 \mathrm{~cm}$ and approximately $15 \%$ over $10 \mathrm{~cm}$ (Fig. 8). Low levels of fragmentation can also be observed among the determinable complete remains which are represented. Thus more than $60 \%$ of auerochs bones are complete and more than $40 \%$ in the case of Haploidoceros (Table 4 ). The low fragmentation of the bones of these species can be observed in Figs. 3-7, where several axial elements are complete.

The same pattern can be observed with regard to the long bones and the representation of their circumference degree (Table 5). Thus, more than $50 \%$ of the Haploidoceros and auerochs long bones have a diaphysis complete circumference degree. This can be observed in Fig. 6, where at least three long bones of Haploidoceros are complete, and also in Fig. 9, where several long bones of auerochs are complete.

Fracture patterns show that most of the long bones from the site are complete (Table 4), and only a few cases of fractures on bones are recorded. Dry fractures due to diagenetic phenomena such as sedimentary pressure (detail of Fig. 9) prevail over green fractures, which are observed in a lesser number of bones: this is two fragments of an undetermined large animal humerus, one femur of Haploidoceros, and five fragments of tibia -two of auerochs, two of undetermined large animal and one of a medium size animal, and one metapodial of Haploidoceros (Table 6).

Analysis of the condition of the bone surfaces and the low levels of weathering shown by the faunal remains suggests that these were quickly buried after death. The same evidence appears to be reinforced with the abundant anatomical connections observed in the auerochs and Haploidoceros carcasses (Figs. 3-7, 9), which were buried prior to postmortem spreading (Weigelt, 1927; Behrensmeyer and Hill, 1980), and also with the good preservation of the bone surfaces, which is characteristic of $70 \%$ of the faunal 
Table 2

Skeletal profiles in MNE identified in PRERESA.

\begin{tabular}{|c|c|c|c|c|c|c|c|c|c|c|c|}
\hline \multirow[t]{2}{*}{ Anatomical parts } & \multirow{2}{*}{$\frac{\mathrm{MNE}}{\mathrm{Bos}}$} & \multirow[t]{2}{*}{$\%$} & \multirow{2}{*}{$\frac{\text { MNE }}{\text { Proboscidea }}$} & \multirow[t]{2}{*}{$\%$} & \multirow{2}{*}{$\frac{\text { MNE }}{\text { Haploidoceros }}$} & \multirow[t]{2}{*}{$\%$} & \multirow[t]{2}{*}{ Equus } & \multirow[t]{2}{*}{ Capreolus } & \multirow[t]{2}{*}{ Panthera. } & \multirow[t]{2}{*}{ Vulpes } & \multirow[t]{2}{*}{ Meles } \\
\hline & & & & & & & & & & & \\
\hline Horn & 2 & 1.6 & 1 & 2.4 & 3 & 2.4 & & & & & \\
\hline Cranium & 1 & 0.8 & 1 & 2.4 & 2 & 1.6 & & & & & 1 \\
\hline Maxillar & 2 & 1.6 & & & 1 & 0.8 & & & & & \\
\hline Mandible & 2 & 1.6 & & & 4 & 3.3 & & & & & \\
\hline Teeth & 22 & 17 & & & 38 & 30.9 & & & 1 & 1 & \\
\hline Vertebrae & 26 & 20 & 6 & 14 & 28 & 22.8 & & & & & \\
\hline Rib & 18 & 14 & 3 & 7.1 & 24 & 19.5 & & & & & \\
\hline Scapula & 2 & 1.6 & 1 & 2.4 & 3 & 2.4 & & 1 & & & \\
\hline Pelvis & 2 & 1.6 & & 0 & 3 & 2.4 & & & & & \\
\hline Humerus & 2 & 1.6 & 1 & 2.4 & 2 & 1.6 & & & & & \\
\hline Femur & 2 & 1.6 & & & 1 & 0.8 & & & & & \\
\hline Radio-Ulna & 3 & 2.2 & 1 & 2.4 & 4 & 3.3 & & & & & \\
\hline Tibiae & 3 & 2.2 & & & 1 & 0.8 & & & & & \\
\hline Metacarpal & 2 & 1.6 & 5 & 12 & 2 & 1.6 & & & & & \\
\hline Metatarsal & 2 & 1.6 & 3 & 7.1 & 1 & 0.8 & & & & & \\
\hline Carpal & 12 & 9.3 & 14 & 33 & & & 1 & & & & \\
\hline Tarsal & 6 & 4.6 & 2 & 4.8 & 1 & 0.8 & & & & & \\
\hline Phalange & 11 & 8.5 & 4 & 10 & 5 & 4.1 & & & & & \\
\hline $\begin{array}{l}\text { Sesamoideal } \\
\text { Indet }\end{array}$ & 9 & 7 & & & & & & & & & \\
\hline Total NR & 129 & 100 & 42 & 100 & 123 & 100 & & & & & \\
\hline Total MNI & 2 & & 1 & & 2 & & & & & & \\
\hline Cranial & 29 & 22 & 2 & 4.8 & 48 & 39 & & & & & \\
\hline Axial & 48 & 37 & 10 & 24 & 58 & 47.2 & & & & & \\
\hline Upper Appendicular & 10 & 8 & 2 & 4.8 & 8 & 6.5 & & & & & \\
\hline Lower Appendicular & 42 & 33 & 28 & 67 & 9 & 7.3 & & & & & \\
\hline
\end{tabular}

Table 3

Skeletal profiles in NISP of small size (size 2), medium size (size 3) and large size (size 4) mammals.

\begin{tabular}{|c|c|c|c|c|c|c|}
\hline \multirow[t]{2}{*}{ Skeletal profiles } & Size 4 & $\%$ & Size 3 & $\%$ & Size $1-2$ & $\%$ \\
\hline & \multicolumn{2}{|l|}{ NISP } & \multicolumn{2}{|l|}{ NISP } & \multicolumn{2}{|l|}{ NISP } \\
\hline Horn & 2 & 1.0 & 6 & 3.7 & & \\
\hline Cranium & 12 & 6.2 & 20 & 12.3 & 2 & 4.8 \\
\hline Maxillar & 1 & 0.5 & 1 & 0.6 & & \\
\hline Mandible & 5 & 2.6 & 5 & 3.1 & 1 & 2.3 \\
\hline Teeth & 20 & 10.3 & 38 & 23.3 & 2 & 4.8 \\
\hline Vertebrae & 42 & 21.5 & 33 & 20.2 & 2 & 4.8 \\
\hline Rib & 30 & 15.4 & 32 & 19.6 & 30 & 71.4 \\
\hline Scapula & 5 & 2.6 & 4 & 2.5 & 2 & 4.8 \\
\hline Pelvis & 7 & 3.6 & 3 & 1.8 & & \\
\hline Humerus or Femur & 5 & 2.6 & 1 & 0.6 & & \\
\hline Humerus & 7 & 3.6 & 2 & 1.2 & 2 & 4.8 \\
\hline Femur & 3 & 1.5 & 1 & 0.6 & & \\
\hline Radius-Ulna & 5 & 2.6 & 4 & 2.5 & 1 & 2.3 \\
\hline Tibiae & 9 & 4.6 & 3 & 1.8 & & \\
\hline Metacarpal & 1 & 0.5 & 2 & 1.2 & & \\
\hline Metatarsal & 3 & 1.5 & 2 & 1.2 & & \\
\hline Carpal and Tarsal & 18 & 9.2 & 1 & 0.6 & & \\
\hline Phalange & 11 & 5.6 & 5 & 3.1 & & \\
\hline Sesamoideal & 9 & 4.6 & & & & \\
\hline Indet & 227 & & 28 & & 36 & \\
\hline Total & 422 & 100 & 191 & 100 & 78 & 100 \\
\hline Cranial & 40 & 21 & 70 & 43 & 5 & 12 \\
\hline Axial & 84 & 43 & 72 & 44 & 34 & 81 \\
\hline Upper Appendicular & 29 & 15 & 11 & 7 & 3 & 7 \\
\hline Lower Appendicular & 42 & 22 & 10 & 6 & & \\
\hline
\end{tabular}

remains (Table 7).

Alterations such as biochemical, trampling or sedimentary corrosion, do not seem to have had a substantial impact on the bone remains. However, hydric alterations have affected an important percentage. Thus, $19.2 \%$ of the remains show evidence of abrasion, $27 \%$ of polishing and $16 \%$ of rolling (Table 7 ). Such alterations suggest that the faunal accumulation of PRERESA has been exposed

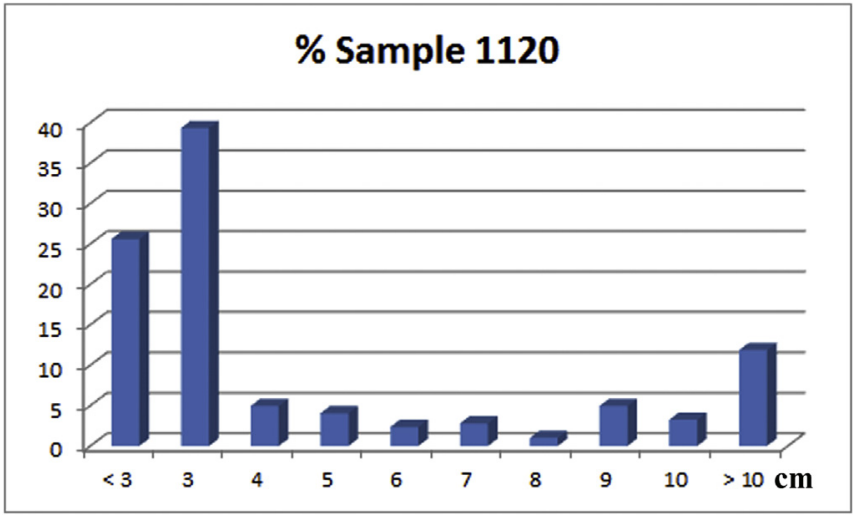

Fig. 8. Fragmentation patterns according to the maximum measurement of the fragments. Remains of proboscideans and teeth fragments have been excluded.

Table 4

Frequencies of representation according to the complete length of the bone. Remains of proboscideans and teeth fragments have been excluded.

\begin{tabular}{llllllll}
\hline \multicolumn{7}{l}{ \% Representation according to the total length of specimen } \\
\hline & $1(<50)$ & $\%$ & $2(>50 \%)$ & $\%$ & $3(100 \%)$ & $\%$ & Total \\
\hline Bos & 23 & 16 & 30 & 21 & 92 & 63 & 145 \\
Haploidoceros & 55 & 47 & 13 & 11 & 50 & 42 & 118 \\
Capreolus & & & 1 & 100 & & 1 \\
indet Small & 70 & 92 & 6 & 8 & & 76 \\
Indet Medium & 54 & 98 & 1 & 2 & & 55 \\
Indet Large & 243 & 96 & 11 & 4 & & 254 \\
Indet & 483 & 100 & 1 & 0 & & 484 \\
\hline
\end{tabular}

to hydric currents, as the site is located in a fluvial context, within the floodplain of the Manzanares River. The minor hydric alterations observed on the bones from PRERESA suggest that low 
Table 5

Frequencies of representation of large bones according to Bunn, 1982) circumference degree.

\begin{tabular}{|c|c|c|c|c|c|c|c|}
\hline \multicolumn{8}{|c|}{$\%$ according to the total circumference degree of large bones } \\
\hline & I & & $\mathrm{C}$ & & $\mathrm{O}$ & $\%$ & Total \\
\hline & $1(<50)$ & $\%$ & $2(>50 \%)$ & $\%$ & $3(100 \%)$ & $\%$ & Total \\
\hline Bos & 4 & 18 & 2 & 9 & 16 & 73 & 22 \\
\hline Haploidoceros & 4 & 36 & 1 & 9 & 6 & 55 & 11 \\
\hline Indet Small & 2 & 100 & & & & & 2 \\
\hline Indet Medium & 3 & 100 & & & & & 3 \\
\hline Indet Large & 6 & 100 & & & & & 6 \\
\hline
\end{tabular}

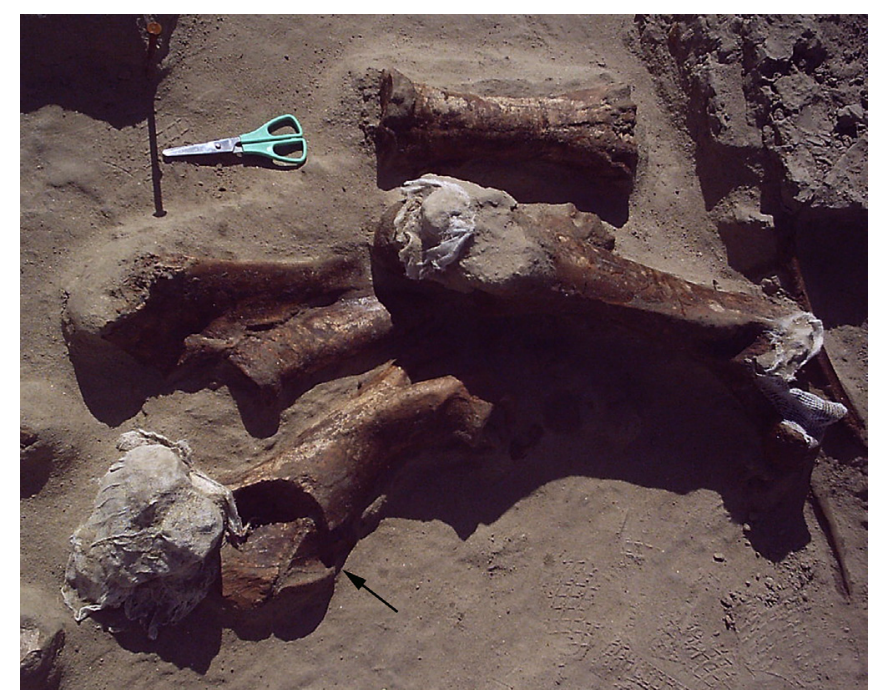

Fig. 9. Ensembles of auerochs complete appendicular bones. Detail of dry fracture on humerus due to sedimentary pressure is pointed with an arrow.

energy currents occurred, as is confirmed by the sedimentary composition of the deposit, consisting of clay and silt. Gravels and pebbles have not been observed at the site, and the low levels of trampling $(<0.3 \%)$ suggests that there were no abrasive substances in the soil that could give rise to this sortof alteration to the bones. Therefore, it is probable that the PRERESA bone remains were deposited before being buried by fluvial deposits.

Alterations such as polishing, abrasion and even rolling could have occurred due to water carrying small particles of silt and clay sliding over the bones, slightly altering the bone surfaces. This
Table 7

Alterations on bones observed in PRERESA. Percentages have been obtained excluding teeth.

\begin{tabular}{lll}
\hline & NISP & $\%$ \\
\hline NISP & 1199 & \\
Bad surface preservation & 364 & 30.4 \\
Weathering & 82 & 6.8 \\
Concretion & 20 & 1.7 \\
Abrasion & 230 & 19.2 \\
Polishing & 324 & 27.0 \\
Rounding & 189 & 15.8 \\
Trampling & 3 & 0.3 \\
Biochemical & 58 & 4.8 \\
Manganese & 917 & 76.5 \\
Rust & 65 & 5.4 \\
Sedimentary Corrosion & 13 & 1.1 \\
\hline
\end{tabular}

phenomenon is well documented in both present day (Thompson et al., 2011) and archaeological studies (Yravedra and Andrés, 2013). Bones with calcareous concretions, or pigmented with manganese dioxide and iron are also alterations due to water action, and occurred as a consequence of precipitation of such substances during periods of flooding produced by low or zero energy.

Despite the fact that water was not the main agent responsible for the formation and accumulation of faunal remains in PRERESA, it may however be an important agent in the bias of some of the assemblage. For example, the lack of certain elements such as carpals and tarsals of medium sized animals are remarkable. This could be related to a higher buoyancy of these elements compared to other bones. As suggested by Voorhies (1969) and Behrensmeyer (1975, 1982, 1988), small and less dense elements are more easily transported by water.

Lastly, activity caused by carnivores or human beings is little documented in the fossil record of PRERESA (Tables 8 and 9). There are nine individuals of horse, roe deer, lion and badger represented at the site, however, barely any assessment of the remains can be carried out. It has already been documented that elephant was intensely exploited by neanderthals, as it presented cut marks and green fractures associated with percussion marks (Yravedra et al., 2012). However, evidence suggests a lack of human intervention with regard to the auerochs and the Haploidoceros. The auerochs was found complete and semi articulated, with one only tooth mark identified on the edge of a rib lower to $2 \mathrm{~mm}$ probably due to a small carnivore that could have manipulated the carcass. The remains of the Haploidoceros were in semi anatomical connection and the lack of cut, tooth and percussion marks suggest that it was not affected by any of these agents.

Table 6

Green and dry fracture patterns on large fractured bones from PRERESA.

\begin{tabular}{|c|c|c|c|c|c|c|}
\hline & & Bos & Haploidoceros & Large Indet & Medium Indet & Small indet \\
\hline \multirow[t]{3}{*}{ Humerus } & Green & & & 2 & & \\
\hline & Dry & 4 & & & & \\
\hline & Indet & 1 & 2 & & & 2 \\
\hline \multirow[t]{3}{*}{ Radius } & Green & & & & & \\
\hline & Dry & 2 & 1 & 1 & & \\
\hline & Indet & 1 & 2 & & & \\
\hline \multirow[t]{3}{*}{ Femur } & Green & & 1 & & & \\
\hline & Dry & 1 & & & & \\
\hline & Indet & 1 & & & & \\
\hline \multirow[t]{3}{*}{ Tibia } & Green & 2 & & 2 & 1 & \\
\hline & Dry & 3 & & & & \\
\hline & Indet & 1 & 1 & 1 & 1 & \\
\hline \multirow[t]{3}{*}{ Metapodial } & Green & & 1 & & & \\
\hline & Dry & 1 & 1 & & 1 & \\
\hline & Indet & 3 & 1 & & & \\
\hline
\end{tabular}


Table 8

Cut marks, (CM), Percussion marks (PM) and Tooth marks (TM) of PRERESA according to NISP with well-preserved bone surfaces and excluding teeth and horn.

\begin{tabular}{lllllllll}
\hline & NISP & CM & $\%$ & PM & $\%$ & TM & $\%$ & Burned \\
\hline $\begin{array}{l}\text { Mammuthus/Elephas } \\
\text { Bos primigenius }\end{array}$ & 40 & 6 & 15 & 7 & 18 & & & \\
$\begin{array}{l}\text { Equus ferus } \\
\text { Haploidoceros }\end{array}$ & 128 & 5 & 4 & & & 2 & 2 & \\
$\begin{array}{l}\text { Capreolus capreolus } \\
\text { Meles meles }\end{array}$ & 107 & & & & & & & \\
& 1 & & & & & & & \\
Indet Large size 4 & 157 & 6 & 4 & 9 & 6 & 4 & 3 & 14 \\
Indet Medium Size 3 & 26 & & & 1 & 4 & 1 & 4 & \\
Indet Small Size 2 & 41 & 1 & 2 & 2 & 5 & 5 & 12 & \\
Indet & 159 & 1 & 1 & 2 & 1 & 1 & 1 & 24 \\
Total & 661 & 19 & 26 & 21 & 34 & 14 & 23 & 38 \\
\hline
\end{tabular}

Table 9

Anatomical distribution of cut, tooth and percussion marks identified in PRERESA.

\begin{tabular}{|c|c|c|c|c|c|c|}
\hline & Bos & Haploidoceros & Size 4 & Size 3 & Size 2 & Indet \\
\hline \multicolumn{7}{|c|}{ Bones with cut marks } \\
\hline Rib & $5(19 \%)$ & & & & $1(3,5 \%)$ & \\
\hline Humerus or femur & & & $1(20 \%)$ & & & \\
\hline Tibia & & & $2(67 \%)$ & & & \\
\hline Indet shaft & & & 3 & & & 1 \\
\hline \multicolumn{7}{|c|}{ Bones with percussion marks } \\
\hline Cranial & & & $1(11 \%)$ & & & \\
\hline Humerus & & & $1(50 \%)$ & & & \\
\hline Humerus or femur & & & $1(20 \%)$ & & & \\
\hline Tibia & & & $2(67 \%)$ & & & \\
\hline Indet shaft & & & & 1 & 2 & 2 \\
\hline \multicolumn{7}{|c|}{ Bones with tooth marks } \\
\hline Cranial & & & $1(11 \%)$ & & & Indet \\
\hline Mandible & $1(33 \%)$ & & & & & \\
\hline Rib & $1(4 \%)$ & $1(3 \%)$ & & & $2(7 \%)$ & \\
\hline Pelvis & & & 1)14\%) & & & \\
\hline Humerus & & & & & $1(50 \%)$ & \\
\hline Indet shaft & & & 2 & & 1 & 1 \\
\hline
\end{tabular}

Furthermore, the green fracture patterns identified on fragments of the other auerochs tibia (Table 6), together with some cut and percussion marks observed on large size animal bones suggest that other mammals were exploited at the site apart from the elephant (Table 8). Cut marks have been identified not only on size 4 , but also on size 2 animals, and percussion marks have been observed on size 2 and 3 animals (Tables 8 and 9).

The comparison carried out on cut marks, according to the reference frame created by various authors (Domínguez-Rodrigo, 1997; Barba and Domínguez-Rodrigo, 2005), showed scant evidence of human activity on the bone sample from PRERESA. However, it does demonstrate that there was human intervention on some mammals other than the proboscidean. This is confirmed by the presence of cut marks on very fragmented pieces of another large bovine, probably another auerochs (Table 8).

Carnivores also took part at the site, however the small size of their marks $(<3 \mathrm{~mm}$ ), the low impact on the bones and the low frequency of these marks show (Tables 8 and 9) that they did not play an important role on the bone accumulation of PRERESA.

\section{Discussion and conclusion}

The faunal analysis of PRERESA shows a complex scene, where lithic industry and bone remains with evidence of human manipulation coexist with other bone remains which show no such evidence.

The species with NISP $>1$ are: one individual of Mammuthus/ Elephas (NISP 82), two individuals of Bos primigenius (NISP 167), and a further two of Haploidoceros mediterraneus (NISP 156), all adults (Table 1). One Haploidoceros and one auerochs are almost completely represented and in semi anatomical connection. Furthermore, 442 bone remains of size 4 animals, 191 of size 3 and 78 of size $1-2$ animals have been recorded. Bones of all anatomical parts are represented in this assemblage (Table 3 ), although carpals and tarsals of size 3 animals are absent (Tables 2 and 3). The presence of less dense anatomical parts, together with the low fragmentation recorded suggests that this is a well preserved sample. Judging by the low levels of identified weathering, the remains of the represented individuals were buried shortly after their death. This is especially relevant in the skeleton of one of the Haploidoceros and one of the auerochs, which are almost complete, in semi anatomical connection, with no evidence of human intervention, and with marginal scavenging from carnivores (Table 9). Both present a large number of complete bones of all anatomical parts: mandibles, ribs, vertebrae, pelvis, and long bones with epiphyses. The anatomical connections, together with the limited weathering of the bones, suggest that these animals died on site, and shortly after clay and silt transported by a flooding event of the river Manzanares -PRERESA is located within this floodplain-buried the remains.

The tooth marks identified on some bones suggest certain activity of carnivores on site. Nevertheless, taphonomic evidence suggests that this would have been a small carnivore, judging by the low impact identified in the bone record. Despite the limitation of its impact, it could have had an influence by spreading, moving and carrying some bones of the carcasses. We have observed how sometimes wolves spread the remains of carcasses a long time after these have stopped being a useful food resource (observed by Yravedra among the wolves from Monte Campelo, Sobrado Dos Montxes, Galicia, Spain). On other occasions, it has been observed that foxes can move the bones of carcasses of cows, sheep and guanacos. The spreading of the remains is proportional to the size of the carcass, thus cows present a very low spreading compared to guanaco or sheep (Estévez and Mameli, 2000).

The most intense human intervention has been identified on the proboscidean individual, in which a significant number of cut and percussion marks that suggest human exploitation of the flesh and the marrow have been recorded (Yravedra et al., 2014). This type of evidence has also been recorded on the most fragmented and dispersed remains of the auerochs, and in other small and medium size mammals. Due to the low number of remains with these marks, the exploitation strategies used by the humans who occupied PRERESA cannot be specified. However, it can be inferred from the recorded cut and percussion marks that apart from the flesh and marrow of the proboscidean, that of other animals were also processed.

With regard to the lithic industry, all phases of the operative chain are represented. Knapping was aimed at flake production, and only some pieces were retouched. It is suggested that the lithic industry was made for processing flesh. This thesis is currently being studied with the development of trace analyses.

The available paleoenvironmental and climatic information extracted from the microfaunal studies (Sesé et al., 2011b; Blain et al., 2013) suggests that PRERESA was located in an environment with forest vegetation and open spaces, consisting of herbaceous plants and river side woodlands associated to the Manzanares river, developed in a temperate climate with some humidity. The presence of pellets on site would suggest the existence of enough forest cover for birds such as owl stonest. Tree, herbaceous or shrub cover could have hidden the auerochs and Haploidoceros carcasses, making them more difficult for carnivores to find. The possibility of a carcass going un noticed in forest environments or with some vegetation is high (Blumenschine, 1986, 
1989; Dominguez-Rodrigo, 1996). In an open environment, these animals would have been scavenged by carnivores such as those described in that stageof the Pleistocene in the surroundings of MJV (Arsuaga et al., 2012). Nevertheless, this thesis, which is feasible on the African continent where most carnivores live in open habitats, cannotnecessarily be adjusted to the European context, specifically to the Iberian Peninsula. Here, other types of carnivores, which move in all type of environments, are very active and are well adapted to different types of ecosystems, such as wolves and foxes, are common. The presence of tree cover would not have prevented these carnivores from detecting the remains of auerochs and Haploidoceros if they had been exposed for some time. Therefore, and taking into consideration that the site is located within the floodplain of the Manzanares river, the most probable thesis is that the corpses of auerochs and Haploidoceros had remained covered, at least partially, shortly after their death, going unnoticed by the various carnivores, including canids.

The slight elaboration of technical schemes of the lithic industry, the scanthuman processing identified on the faunal remains, and the presence of animals laiddown in a natural way suggest that this site could have been used by Neanderthals in isolated moments. However, the presence of several taxa such as proboscidean, auerochs and other size 4 mammals with signs of human processing could suggest that the site was visited recurrently by human groups with the purpose of processing such mammals.

Extending the area of excavation will enable us to tackle issues relating not only to the way but also to the time of year in which meat sources were acquired. The Haploidoceros antlers suggest that it died sometime in autumn or winter, probably towards the end of this season. However, the lack of direct evidence of human activity on this specimen does not allow us to link the presence of human groups in this season with certainty.

The issue of possible territory management by Neanderthals in the MJV can be discussed in relation to the site at PERESA.

In most of the published sites of Manzanares, such as La Gavia, Los Estragales, HAT, El Cañaveral, Los Ahijones, among others, only the lithic industry is preserved (López-Recio et al., 2005; Panera et al., 2005; Pérez-González et al., 2008; Baena et al., 2008a, 2008b, 2015; Rubio-Jara, 2011) and not the faunal remains. Therefore only the management of raw lithic material can be researched. Even though more evidence of human exploitation of fauna during the Middle Palaeolithic is known from sites such as Santa Elena, Viuda de Martínez, Santa Catalina, La Aldehuela, and Pedro Jaro (Panera et al., 2014; Yravedra et al., 2014), these are only occasional finds that have not been retrieved from a systematic excavation, and therefore the available information is limited. Systematic excavations have only been carried out at EDAR Culebro 1 and Arriaga IIa. However, only green-bone fracture patterns have been identified in EDAR Culebro 1, on the remains of a sub-adult male of M. Primigenius (Álvarez-Lao and García, 2011; Yravedra et al., 2014). On the other hand, Arriaga IIa was excavated in the early 1980's (Rus and Vega, 1984; Silva et al., 2013), but the bone remains present preservation problems that make observation of the taphonomic processes associated with human beings difficult (Panera et al., 2014).

PRERESA is one of the open air-sets in MJV where a well contextualised asssociation of lithic industry and faunal remains has been recorded. The good preservation of the faunal remains allows the analysis of the degree of human intervention over the remains of proboscidean, auerochs and other mammals. Furthermore, PRERESA is one of the few open air sites of the end of the Middle Pleistocene/early Late Pleistocene of the Iberian Peninsula with evidence of Neanderthal exploitation of the faunal remains.

\section{Acknowledgements}

The archaeological excavation of PRERESA has been funded by the Dirección General de Patrimonio Histórico (PR170/04-13244; PR42/05-14071; 1962/2006/00) and the Dirección General de Investigación of Comunidad de Madrid (06/123/2003). We wish to express our gratitude to Iván González, Nuria Gallego, Primitivo Javier Sanabria Marcos and Miguel Díaz Moreno for supervising the excavation works, and to Juan Antonio Mondéjar for the restoration of the faunal remains. We would like to thank Museo Arqueológico Regional de Madrid and its director, Enrique Baquedano, for his help on extraction and restoration of a great deal of the fauna recorded at PRERESA, especially the Haploidoceros mediterraneus.

\section{Appendix A. Supplementary data}

Supplementary data related to this article can be found at https://doi.org/10.1016/j.quaint.2018.01.030.

\section{References}

Álvarez-Lao, D.J., García, N., 2011. Southern dispersal and Palaeoecological implications of woolly (Coelodonta antiquitatis): review of the Iberian occurrences. Quat. Sci. Rev. 30, 2002-2017.

Arche, A., 1983. Coarse-grained meander lobe deposits in the Jarama river, Madrid. Spain. In: Collinson, J.D., Lewin, J. (Eds.), Meander and Ancient Fluvial Systems. International Association Sedimentology, pp. 313-321. Special Publication 6.

Arsuaga, J.L., Baquedano, E., Pérez-González, A., Sala, N., 2012. Understanding the ancient habitats of the last-interglacial (late MIS 5) Neanderthals of central Iberia: paleoenvironmental and taphonomic evidence from the Cueva de Camino (Spain) site. Quat. Int. 275, 55-75.

Baena Preysler, J., Baquedano, I. (Eds.), 2010. Las huellas de nuestro pasado. Estudio del Yacimiento del pleistoceno madrileño de Tafesa (Antigua Transfesa). Zona Arqueológica, 14

Baena, J., Bárez, S., Pérez-González, A., Lázaro, A., Nebot, A., Roca, M., Pérez, T. González, I., Cuartero, F., Rus, I., Polo, J., Márquez, R., Cabanes, I., Cruelles, D. Carrancho Alonso, A., 2008. El yacimiento paleolítico Cañaveral (CosladaMadrid). La captación de recursos líticos durante el Musteriense peninsular ARQ 9 (2), 1-32.

Baena, J., Ortiz, I., Torres, C., Bárez, S., 2015. Recycling in abundance: re-use and recycling processes in the Lower and Middle Paleolithic contexts of the central Iberian Peninsula. Quat. Int. 361, 142-154.

Baena, J., Polo, J., Bárez, S., Cuartero, F., Roca, M., Lázaro, A., Nebot, A., PérezGonzález, A., Pérez, T., Rus, I., Rubio, D., Martín Puig, D., Manzano, C. González, I., Márquez, R., 2008. Tecnología musteriense en la región madrileña: un discurso enfrentado entre valles y páramos de la Meseta sur. Treballs arqueol. 14, 249-278.

Baena, J., Rus, I., Cuartero, F., Martín, D., Rubio, D., Roca, M., 2010. Estudio tec nológico de la industria lítica del yacimiento de Las Cien Fanegas (Madrid) en e contexto Achelense de la Meseta. Cuaternario y Arqueología: Homenaje a Francisco Giles Pacheco. Diputación Provincial de Cádiz, Cádiz, pp. 71-83.

Barba, R., Domínguez-Rodrigo, M., 2005. The taphonomic relevance of the analysis of bovid long limb bone shaft features and their application to element identification: study of bone thickness and morphology of the medullary cavity. J. Taphonomy 3, 17-42.

Bárez del Cueto, S., Baena Preysler, J., Pérez-González, A., Torres, C., Pérez, I.R., de Miguel, J.V., 2016. Acheulian flint quarries in the Madrid Tertiary basin, central Iberian Peninsula: first data obtained from geoarchaeological studies. Quat. Int. $411,329-348$.

Behrensmeyer, A.K., 1975. The Taphonomy and Paleoecology of Plio-Pleistocene vertebrate assemblages east of lake Rudolf, Kenya. Bull. Mus. Comp. Zool. 146, 473-578

Behrensmeyer, A.K., 1978. Taphonomic and ecological information from bone weathering. Paleobiology 4, 150-162.

Behrensmeyer, A.K., 1982. Time resolution in fluvial vertebrate assemblages. Paleobiology 4 (2), 150-162.

Behrensmeyer, A.K., 1988. Vertebrate preservation in faunal chanels. Palaeogeography, paleoclimatology. Plaeoecology 63, 183-199.

Behrensmeyer, A.K., Hill, A. (Eds.), 1980. Fossils in the Making. Vertebrate Taphonomy and Paleoecology. Chicago.

Bischoff, J.L., García, J.F., Straus, L.G., 1992. Uranium-series isochron dating at el Castillo cave (Cantabria, Spain): the "Acheulean"|"Mousterian" question. J. Archaeol. Sci. 19, 49-62.

Blain, H.A., Sesé, C., Panera, J., Rubio-Jara, S., Uribelarrea, D., Pérez-González, A. 2013. Reconstitution paléoenvironnementale et paléoclimatique du Pléistocène supérieur ancien (MIS 5a) dans le centre de l'Espagne: les petits vertébrés (amphibia, reptilia \& mammalia) des gisements de Hat et PRERESA (sud-est de Madrid). Quaternaire 24 (2), 191-205. 
Blasco, R., Fernández Peris, J., 2012. A uniquely broad spectrum diet during the middle Pleistocene at Bolomor cave (Valencia, Spain). Quat. Int. 252, 16-31.

Blasco, R., Fernández Peris, J., 2012. Small and large game: human use of diverse faunal resources at Level IV of Bolomor Cave (Valencia, Spain). Comptes Rendus Palevol 11 (4), 265-282.

Blumenschine, R.J., 1986. Early Hominid Scavenging Opportunites. Implications of Carcass Availability in the Serengeti and Ngorongoro Ecosystems. BAR International Series 283.

Blumenschine, R.J., 1988. An experimental model of the timing of hominid and carnivore influence on archaeological bone assemblages. J. Archaeol. Sci. 15, $483-502$.

Blumenschine, R.J., 1989. A landscape taphonomic model of the scale of prehistoric scavenging opportunities. J. Hum. Evol. 18, 345-371.

Blumenschine, R.J., 1995. Percussion marks, tooth marks, and experimental determinations of the timing of hominid and carnivore access to long bones at FLK Zinjanthropus, Olduvai Gorge, Tanzania. J. Hum. Evol. 29, 21-51.

Brain, C.K., 1969. The contribution of Namib desert Hottentots to understanding of Australopithecus bone accumulations. Sci. Pap. Namib. Desert Res. Stat. 32 $1-11$.

Bunn, H.T. 1982. Meat-eating and Human Evolution, Studies on the Diet and Subsistence Patterns of Plio-pleistocene Hominids in East Africa. Ph.D. thesis. University of California at Berkeley, p. 384.

Cabrera, V., 1984. El Yacimiento de la Cueva de "El Castillo". Biblioteca Prehistórica Hispana 22, Madrid.

Carrillo, L., Gisbert, J., Arche, A., 1978. Modelo de sedimentación de la terraza baja (+18-20) del río Manzanares. Estud. Geol. 34, 549-552.

De los Arcos, S., Gallego, N., Gil Ortiz, C., González García, I., Yravedra, J., 2008 Geoarqueología del yacimiento paleolítico del Estanque de Tormentas de Butarque (Villaverde, Madrid). OrJIA (Coord.). In: Actas de las I Jornadas de Jóvenes en Investigación Aqueológica. (Madrid, 3-5 septiembre de 2008). Dialogando con la cultura material I, pp. 135-140.

Díez, J.C., 2007. Huellas de descarnado en el Paleolítico Medio: La cueva de Valdegoba, Burgos. Zona Arqueológica 7, 304-317.

Domingo, R. Peñá-Monné, J.L., Torres, T. Ortiz, J.E. Utrilla, P. 2017. Neandertha highlanders: las Callejuelas (Monteagudo del Castillo, Teruel, Spain), a high altitude site occupied during MIS 5. Quat. Int. 435, 129-143.

Dominguez-Rodrigo, M., 1996. A lanscape study of bone conservation in the Galana and Kulalu (Kenya) ecosystem. Origini 20, 17-38.

Domínguez-Rodrigo, M., 1997. Meat eating by early hominids at FLK Zinj 22 Site Olduvay Gorge Tanzania, an experimental a roach using cut-mark data. J. Hum. Evol. 33, 669-690.

Domínguez-Rodrigo, M., de Juana, S., Galán, A.B., Rodríguez, M., 2009. A new protocol to differentiate trampling marks from butchery cut marks. J. Archaeol. Sci. 36, 2643-2654.

Estévez, J., Mameli, L., 2000. Muerte en el canal: experiencias bioestratinómicas controladas sobre la acción sustractora de cánidos. ARCHAEOFAUNA 9, 7-16.

Foury, Y., Desclaux, E., Daujeard, C., Defleur, A., Moncel, M.H., Raynal, J.P., 2016 Evolution des faunes de rongeurs en moyen nevallée du Rhône (Rivedroite. Ardèche, France) aucours du Pléistocène Moyen final et du PléistocèneSupérieurancien, du MIS6 au MIS4. Quaternaire 27 (1), 55-79.

Goy, J.L., Pérez-González, A., Zazo, C., 1989. Cartografía geológica del Cuaternario, geomorfología y Memoria correspondiente de la Hoja a E. 1:50.000 de Madrid (559). Instituto Tecnológico Geológico y Minero de España, Madrid.

Jiménez-Arenas, J.M., Santonja, M., Botella, M., Palmqvist, P., 2011. The oldest handaxes in Europe: fact or artefact? J. Archaeol. Sci. 38 (12), 3340-3349.

Laplana, C., Herráez, E., Yravedra, J., Bárez, S., Uribelarrea, D., Rubio-Jara, S. Panera, J., Pérez-González, A., 2015. Biocronología de la Terraza Compleja de Butarque en el río Manzanares en el Estanque de Tormentas al sur de Madrid. Estud. Geol. 71 (1), e028. https://doi.org/10.3989/egeol.41808.338.

López Recio, M., Manzano Espinosa, I., Romero Salas, H., Escalante García, S., PérezGonzález, A., Conde Ruiz, C., Velázquez Rayón, R., Baena Preysler, J., Carrión Santafé, E 2005. Caracterización geoarqueológica de depósitos cuaternarios de Arroyo de La Gavia (Cuenca del río Manzanares, Madrid). In: Santonja, M. Pérez-González, A., Machado, M.J. (Eds.), Geoarqueología y Patrimonio en la Península Ibérica y el entorno Mediterráneo ADEMA, Soria, pp. 261-272.

Made, J. van der, Mazo, A., 2015. Los grandes mamíferos del yacimiento de PRERESA- En Haploidoceros mediterraneus Una nueva especie de ciervo en e Pleistoceno ibérico. In: Baquedano, I., La Plana, C. (Eds.), Museo Arqueológico Regional. Alcalá de Henares, Madrid, pp. 59-74.

Márquez, B., Mosquera, M., Baquedano, E., Pérez-González, A., Arsuaga, J.L. Panera, J., Espinosa, J.A., Gómez, J., 2013. Evidence of a Neanderthal- made quartz-based technology at Navalmaíllo rock shelter (Pinilla del Valle, Madrid Region, Spain). J. Anthropol. Res. 69 (3), 373-395.

Martín Penela, A., 1987. Paleontología de los grandes mamíferos del yacimiento achelense de la Solana del Zamborino (Fonelas, Granada). Antropol. Paleoecol. humana 5, 29-188.

Moreno, D., Duval, M., Rubio-Jara, S., Panera, J., Bahain, J.J., Shao, Q., PérezGonzález, A., Falguères, C., 2017. ESR dating of several Middle to Late Pleistocene archaeo-paleontological sites from the Manzanares and Jarama river valleys (Madrid basin, Spain). Quat. Int. https://doi.org/10.1016/j.quaint.2017.09.003.

Panera, J., Pérez-González, A., Rubio-Jara, S., Sesé, C., 2005. El yacimiento paleolítico de HAT en el valle del Jarama: una aportación de Cuaternario de la cuenca de Madrid al debate sobre el inicio del Paleolítico medio. In: Santonja, M., Pérez-
González, A., Machado, M.J. (Eds.), Geoarqueología y Patrimonio en la Península Ibérica y el entorno Mediterráneo ADEMA, Soria, pp. 251-260.

Panera, J., Rubio-Jara, S. (Eds.), 2002. Bifaces y elefantes. La investigación del Paleolítico Inferior en Madrid, p. 510. Zona Arqueológica 1.

Panera, J., Rubio-Jara, S., Yravedra, J., Blain, H.A., Sesé, C., Pérez-González, A., 2014. Manzanares Valley (Madrid, Spain): a good country for proboscideans and Neanderthals. Quat. Int. 326-327, 329-343.

Panera, J., Torres, T., Pérez-González, A., Ortiz, J.E., Rubio-Jara, S., Uribelarrea, D., 2011. Geocronología de la Terraza Compleja de Arganda en el valle del río Jarama (Madrid, España). Estud. Geol. 67 (2), 495-504.

Pérez-González, A., 1971. Estudio de los procesos de hundimiento en el valle del río Jarama y sus terrazas (nota preliminar). Estudios Geológicos XXVII 4, 317-324.

Pérez-González, A., Rubio-Jara, S., Panera, J., Uribelarrea, D., 2008. Geocronología de la sucesión arqueoestratigráfica de Los Estragales en la Terraza Compleja de Butarque (Valle del río Manzanares, Madrid). Geogaceta 45, 39-42.

Rubio-Jara, S., 2011. El paleolítico en el valle del río Manzanares (Madrid) Caracterización geoarqueológica de depósitos pleistocenos y estudio tecnoeconómico de la industria lítica. Ph.D. thesis. Universidad Nacional de Educación a Distancia.UNED Madrid., p. 607

Rubio-Jara, S., Panera, J., Rodríguez de Tembleque, J., Santonja, M., PérezGonzález, A., 2016. Large flake Acheulean in the middle Tagus basin (Spain): middle stretch of the river Tagus valley and lower stretches of the rivers Jarama and Manzanares valleys. Quat. Int. 411, 349-366.

Rus, I., Vega, G., 1984. El yacimiento de Arriaga II: problemas de una definición actual de los suelos de ocupación. In: Primeras Jornadas de Metodología e Investigación Prehistórica (Soria, 1981). Ministerio de Cultura, pp. 387-404.

Santonja, M., López Martínez, N., Pérez-González, A. (Eds.), 1980. Ocupaciones Achelenses en el Valle del Jarama (Arganda, Madrid). Arqueología y Paleoecología 1. Diputación Provincial de Madrid, p. 352.

Sañudo, P., Blasco, R., Fernández-Peris, J., 2016. Site formation dynamics and human Occupations at Bolomor Cave (Valencia, Spain): an archaeostratigraphic analysis of levels I to XII (100-200 ka). Quat. Int. 417, 94-104.

Sesé, C., Panera, J., Rubio-Jara, S., Pérez-González, A., 2011. Micromamíferos del Pleistoceno Medio y Pleistoceno Superior en el Valle del Jarama: yacimientos de Valdocarros y HAT (Madrid). Estud. Geol. 67 (1), 131-151.

Sesé, C., Rubio-Jara, S., Panera, J., Pérez-González, A., 2011. Micromamíferos del Pleistoceno Superior del yacimiento de PRERESA en el valle del Manzanares y su contribución a la reconstrucción paleoambiental de la cuenca de Madrid durante el Pleistoceno. Estud. Geol. 67 (2), 471-494.

Sesé, C., Soto, E., 2002. Catálogo de los yacimientos de Vertebrados del Pleistoceno en las terrazas de los ríos Jarama y Manzanares. In: Panera, J., Rubio-Jara, S. (Eds.), Bifaces y elefantes. La investigación del Paleolítico Inferior en Madrid, vol. 1. Museo Arqueológico Regional de la Comunidad de Madrid, Zona Arqueológica, pp. 430-457.

Sesé, C., Soto, E., 2002. Vertebrados del Pleistoceno del Jarama y Manzanares. In: Panera, J., Rubio-Jara, S. (Eds.), Bifaces y elefantes. La investigación del Paleolítico Inferior en Madrid, vol. 1. Museo Arqueológico Regional de la Comunidad de Madrid, Zona Arqueológica, pp. 318-337.

Silva, P.G., López-Recio, M., Tapias, F., Roquero, E., Morín, J., Rus, I., CarrascoGarcía, P., Giner-Robles, J.L., Rodríguez-Pascua, M.A., Pérez-López, R., 2013. Stratigraphy of the Arriaga Palaeolithic sites. Implications for the geomorphological evolution recorded by thickened fluvial sequences within the Manzanares River valley (Madrid Neogene Basin, Central Spain). Geomorphology $196,138-161$.

Thompson, C.E., Ball, S., Thompson, T.J.U., Gowland, R., 2011. The abrasion of modern and archaeological bones by mobile sediments: the importance of transport modes. J. Archaeol. Sci. 38, 784-793.

Villa, P., 1990. Torralba and Aridos: elephant exploitation in MP Spain. J. Hum. Evol. 19, 299-309.

Villa, P., Mahieu, E., 1991. Breakage patterns of human long bones. J. Hum. Evol. 21, $27-48$.

Voorhies, M., 1969. Taphonomy and Population Dynamics of an Early Pliocene Vertebrate Fauna, Knox Country, Nebraska. Special Paper 1. Univ. of Wyoming Press Department of Geology and Geophysics, p. 69.

Weigelt, J., 1927. Recente Wirbeltierleichen und ihrepaleobiologisch e Bedentung. Leipzig)

Yravedra, J., 2010. Estudio tafonómico y zooarqueológico de los macromamíferos del yacimiento arqueológico de Tafesa (Villaverde Bajo, Mabrid). In: Baena, J., Baquedano, I. (Eds.), Las huellas de nuestro pasado. Estudio del Yacimiento de pleistoceno madrileño de Tafesa (Antigua Transfesa). Zona Arqueológica, vol. 14, pp. 155-176.

Yravedra, J. Andrés, M., 2013. Estrategias de subsistencia entre los grupos magdalenienses de La Peña de Estebanvela (Ayllón, Segovia). In: Cacho C. (Coord). Ocupaciones magdaleniense en el interior de la Península Ibérica. La Peña de Estebanvela, Ayllón, Segovia, pp. 213-244.

Yravedra, J. Domínguez-Rodrigo, M., 2009. The shaft-based methodological approach to the quantification of long limb bones and its relevance to understanding hominin subsistence in the Pleistocene: application to four Paleolithic sites. J. Quat. Sci. 24, 85-96.

Yravedra, J., Domínguez-Rodrigo, M., Santonja, M., Pérez González, A., Panera, J., Rubio-Jara, S., Baquedano, E., 2010. Cut marks on the middle Pleistocene elephant carcass of Áridos 2 (Madrid, Spain). J. Archaeol. Sci. 37, 2469-2476.

Yravedra, J., Panera, J., Rubio-Jara, S., Manzano, I., Exposito, A., Pérez-González, A., 
Soto, E., López-Recio, M., 2014. Neanderthal and Mammuthus interactions at EDAR Culebro 1 (Madrid, Spain). J. Archaeol. Sci. 42, 500-508.

Yravedra, J., Rubio-Jara, S., Panera, J., Martos, J.A., 2017. Hominins and proboscideans in the lower and middle palaeolithic in the central iberian Peninsula. Quat. Int. https://doi.org/10.1016/j.quaint.2017.12.002.
Yravedra, J., Rubio-Jara, S., Panera, J., Uribelarrea, D., Pérez-González, A., 2012. Elephants and subsistence. Evidence of the human exploitation of extremely large mammal bones from the Middle Palaeolithic site of PRERESA (Madrid, Spain). J. Archaeol. Sci. 39 (4), 1063-1071.

Please cite this article in press as: Yravedra, J., et al., Neanderthal diet in fluvial environments at the end of the Middle Pleistocene/early Late Pleistocene of PRERESA site in the ManzanaresValley (Madrid, Spain)., Quaternary International (2018), https://doi.org/10.1016/ j.quaint.2018.01.030 